\title{
Kontribusi Corporate Governance Dalam Mengurangi Kecurangan Laporan Keuangan
}

\author{
Arief Mulyadianto $^{(1)}$, Dwi Jaya Kirana ${ }^{(2)}$, Aniek Wijayanti ${ }^{(3)}$ \\ Universitas Pembangunan Nasional Veteran Jakarta \\ EMail: (1)arief.mulyadianto@upnvj.ac.id ${ }^{(2)}$ dwijayakirana@upnvj.ac.id \\ ${ }^{(3)}$ aniekwijaya@upnvj.ac.id
}

\begin{abstract}
ABSTRAK
Penelitian ini punya tujuan untuk menganalisis peranan corporate governance untuk mengurangi kecurangan laporan keuangan. Variabel yang dipakai pada penelitian ini yakni performa dewan komisaris, keahlian keuangan komite audit dan kepemilikan institusional sebagai variabel independen dan untuk variabel dependen menggunakan kecurangan laporan keuangan dengan proksi Beneish M-Score. Sampel yang dipakai dalam penelitian ini yakni perusahaan manufaktur yang tercatat di Bursa Efek Indonesia. Teknik analisis data menggunakan SPSS dengan tingkat signifikansi 5\%. Hasil penelitian ini yakni performa dewan komisaris dan kepemilkan institusional berpengaruh untuk mengurangi kecurangan laporan keuangan sedangkan keahlian keuangan komite audit tidak berpengaruh dalam mengurangi kecurangan laporan keuangan.
\end{abstract}

Kata Kunci: performa dewan komisaris, keahlian keuangan komite audit, kepemilikan institusional, kecurangan laporan keuangan, beneish $\mathrm{m}$-score.

\section{ABSTRACT}

This research was conducted to test and find out the role of corporate governance in reducing financial statement fraud. The variables used in this study are the performance of the board of commissioners, audit committee financial expertise, and institutional ownership as an independent variable and for the dependent variable using fraudulence financial statements with the Beneish $M$ Score proxy. The sample used in this study is manufacturing companies listed on the Indonesia Stock Exchange. The analysis technique used uses SPSS with a significance level of 5\%. The results of this study are the performance of the board of commissioners, audit committee financial expertise and institutional ownership does not affect reducing fraudulence financial statements.

Keywords: the performance of the board of commissioners, audit committee financial expertise, institutional ownership, fraudulence financial statements, beneish $m$-score.

\section{PENDAHULUAN}

Laporan keuangan ialah suatu tulisan penjelasan informasi keuangan sebuah perusahaan di sebuah fase periode akuntansi yang bisa dimanfaatkan agar mendeskripsikan prestasi kerja pada suatu perusahaan. Tujuan laporan keuangan yaitu untuk membagikan suatu keterangan terkait kinerja, situasi keuangan dan peralihan situasi keuangan (IAI, 2018). Laporan keuangan bisa digunakan menjadi panduan untuk pengguna laporan keuangan eksternal perusahaan contohnya misal investor, menjadi landasan penentuan ketetapan. Satu diantara konstituen yang amat krusial pada laporan keuangan yakni laporan laba/rugi. Laporan laba/rugi ialah satu dari tiga laporan keuangan yang dipakai guna memberitahukan keuangan sebuah perusahaan sepanjang satu periode, beserta sama neraca keuangan serta laporan arus kas. Laporan tersebut

\section{JIAKES}


Corporate

Governance and

Fraudulance

adalah laporan awal yang amat biasa sebab data yang diperlukan jelas, simpel dan dapat digunakan dalam pengambilan keputusan. Contoh data yang paling penting yaitu laba, dari laba dapat diketahui performa perusahaan setiap tahunnya.

Satu diantara perkara yang sudah berlangsung di Indonesia yaitu kasus di dunia perbankan nasional pada PT Bank Bukopin Tbk, dengan cara memodifikasi atau mengubah laporan keuangan, yang menimbulkan posisi kredit serta penghasilan berdasar komisi bukopin meningkat tidak sewajarnya. Bank Bukopin melakukan perubahan laba bersih pada tahun 2016 jadi Rp 183,5 Miliar yang sebelumnya berjumlah Rp 1,08 Triliun, lalu penyusutan paling besar terjadi pada bagian penghasilan provisi serta komisi yang mewujudkan penghasilan atas kartu kredit yaitu sebesar $\mathrm{Rp}$ 317,8 Miliar yang sebelumnya berjumlah $\mathrm{Rp}$ 1,06 Triliun. Selain dari permasalahan kartu kredit, perubahan pula berlangsung untuk pembiayaan anak usaha Bank Syariah Bukopin (BSB) mengenai peningkatan saldo cadangan kerugian penyusutan nilai debitur, perubahan tersebut mengakibatkan tanggungan eliminasi kerugian nilai untuk aset keuangan menimbulkan peningkatan sebesar Rp 797,6 Miliar yang sebelumnya berjumlah Rp 649,05 Miliar, keadaan tersebut mengakibatkan tanggungan perseroan bertambah Rp 148,6 Miliar (Cncb Indonesia, 2018).

Peristiwa kecurangan dengan memanipulasi laporan keuangan yang kerap berlangung pada masa modern saat ini, harus ada sebuah sistem dengan prosedur yang baik untuk mengurangi tindakan kecurangan laporan keuangan yang kerap dinyatakan yakni Good Corporate Governance. Bersama terdapatnya sistem manajemen perusahaan yang didukung oleh prosedur, diharapkan dapat mengatasi krisis keuangan ataupun non-keuangan perusahaan dan mampu menaikan efektivitas dan efisiensi dari pengelolaan bisnis perusahaan.

Dalam rangka memotivasi perusahaan publik supaya mengimplementasikan manajemen perusahaan yang bagus, pemerintah dan para regulator lainnya telah mengeluarkan berbagai macam peraturan mengenai pelaksanaan tata kelola perusahaan, satu diantaranya yakni Peraturan OJK Nomor 21/POJK.04/2015 Terkait Penerapan Pedoman Tata Kelola Perusahaan Terbuka. Dengan diterapkannya tata kelola yang tepat, dicita-citakan mekanisme kontrol dalam perusahaan bakal berjalan secara sendirinya, sehingga perusahaan dapat memberikan perfoma yang baik yang nantinya akan tercermin pada laporan keuangan dan tahunan perusahaan.

Peraturan lainnya adalah Ketetapan Direksi BEI Jakarta Nomor: Kep-305/BEJ/072004 Terkait Peraturan Nomor I-A Terkait Pencatatan Saham serta Efek Bersifat Ekuitas di Bursa. Regulasi tersebut menyebutkan mengenai perusahaan diharuskan memiliki anggota independen pada struktur Dewan Komisaris serta Direksi, Komite Audit, serta Sekretaris Perusahaan. Berkaitan dengan Dewan Komisaris, Undang-Undang Nomor 40 Tahun 2007 Terkait Perseroan Terbatas menyebutkan bahwa sebuah perusahaan publik mempunyai tiga Organ Perseroan, ialah RUPS, Direksi, serta Dewan Komisaris. Ketiga Organ itu dengan berbarengan melangsungkan fungsi serta kewajibannya tiap-tiap supaya memperoleh target perusahaan. Meskipun RUPS merupakan Organ Perseroan tertinggi, tugas serta tanggung jawab yang dibagikan pada Dewan Komisaris memiliki dampak sangat besar terhadap kegiatan yang dilakukan perusahaan. Dengan kata lain, kinerja yang dibagikan dari Dewan Komisaris akan menentukan apakah perusahaan telah menerapkan tata kelola perusahaannya secara baik.

Undang-undang Nomor 40 Tahun 2007 Terkait Perseroan Terbatas mengemukakan mengenai fungsi pokok Dewan Komisaris adalah melaksanakan fungsi pengawasan serta memberi nasihat untuk penyelenggaraan perseroan yang dilakukan oleh Direksi. Hsu dan $\mathrm{Wu}$ (2014) menyebutkan bahwa efektivitas kinerja dari Dewan Komisaris akan menentukan dan memengaruhi kesuksesan dari sebuah perusahaan. Hal ini dikarenakan Dewan Komisaris harus dapat memastikan perusahaan berjalan sesuai dengan kepentingan pemegang saham (Volonté, 2015).

Ketika melakukan tugasnya, Dewan Komisaris bisa didukung dari beberapa komite, salah satunya yakni Komite Audit. Komite Audit ialah komite yang bertindak secara tidak terikat serta memiliki tanggung jawab terhadap Dewan Komisaris untuk 
mendukung melangsungkan peran serta kewajiban Dewan Komisaris. Pada kaitannya dengan kesempatan berlangsungnya kecurangan pada laporan keuangan, prestasi kerja Komite Audit punya pengaruh yang cukup besar kepada peluang terjadinya salah catat atau misstatement pada laporan keuangan (Veronica dan Bachtiar, 2005). Keadaan tersebut dikarenakan Komite Audit memiliki peranan yang teramat krusial untuk melaksanakan pemeriksaan terhadap informasi keuangan yang bakal diinformasikan dari perusahaan (Ketetapan Ketua Badan Pengawas Pasar Modal dan Lembaga Keuangan Nomor: KEP-643/BL/2012).

Komite Audit pula perlu mempunyai keilmuan pada aspek keuangan ataupun mempunyai dasar akuntansi. Bersumber pada Peraturan OJK No. 55/POJK.04/2015, anggota komite audit mempunyai syarat independen serta sedikitnya ada seorang yang mempunyai keahlian pada asepek keuangan ataupun akuntansi. Melainkan daripada itu anggota komite audit harus mengetahui laporan keuangan, bisnis perusahaan spesifiknya yang berhubungan pada pelayanan jasa ataupun aktivitas bisnis emiten ataupun perusahaan publik, proses audit, manajemen risiko, serta kebijakan perundang-undangan di sektor pasar modal dan kebijakan perundang-undangan mengenai lain-lain.

Pada tahun 2006, Chen et al.melakukan penelitian mengenai kecurangan akuntansi di China serta mengaitkan kecurangan pada variabel kepemilikan. Struktur kepemilikan mampu mempengaruhi jalannya perusahaan, dimana hal tersebut berpengaruh terhadap kinerja suatu perusahaan. Koh (2003) mengemukakan mengenai di perusahaan di Australia yang memiliki kepemilikan institusional yang besar dapat mendesak tata kelola laba yang agresif oleh perusahaan, yang mana kepemilikan institusional berperan selaku metode corporate governance.

Roberts dan Yuan (2009) yang menandakan mengenai kepemilikan institusional yang tinggi bisa mempersembahkan dorongan supaya melaksanakan pemeriksaan atau pengamatan yang makin cermat kepada prestasi kerja manajemen hingga kemungkinan manajemen agar melangsungkan kecurangan terhadap laporan keuangan bakal makin kecil. Keadaan tersebut disebabkan keperluan ekonomi investor institusional jadi makin tinggi untuk entitas itu hingga satu diantara aspek yang punya pengaruh pada monitoring terhadap kinerja manajemen adalah kepemilikan institusional. Sebab demikan, kepemilikan institusional yang semakin tinggi dalam suatu perusahaan bakal mengurangi kecurangan dalam laporan keuangan.

Berdasarkan fenomena serta gap research, peneliti tertarik melakukan penelitian yang berjudul "Peranan Corporate Gocernance dalam Mengurangi Kecurangan Laporan Keuangan". Riset ini merujuk dari riset terdahulu Priswita (2019) yang memiliki judul Pengaruh Corporate Governance terhadap Kecurangan Laporan Keuangan. Terdapat perihal yang berbeda dari riset ini dengan terdahulunya yakni terletak pada variabel. Dimana penelitian sebelumnya menurut Priswita (2019), menggunakan variabel komite audit untuk memperlihatkan mengenai komite audit yang mempunyai pengaruh kepada kecurangan laporan keuangan, hingga pada riset ini saya mengganti variabel tersebut dengan keahlian keuangan komite audit untuk mengurangi kecurangan laporan keuangan.

\section{METODOLOGI PENELITIAN}

Jenis penelelitian ini adalah penelitian kuantitatif dan data yang digunakan yaitu data sekunder. Populasi pada riset ini yakni sektor manufaktur yang tercatat pada BEI (Bursa Efek Indonesia) tahun 2016-2018. Perusahaan yang sudah go public cenderung memiliki peluang yang lebih tinggi dalam melakukan tindakan kecurangan dibandingkan perusahaan yang belum go public. Pada kurun waktu tahun 2016-2018, total perusahaan manufaktur yang tercatat pada BEI per 31 Desember 2018 yakni sebesar 166 perusahaan. Pengambilan sampel pada riset ini dilaksanakan memakai metode purposive sample yakni pemilihan sampel berdasarkan kesamaan karakteristik sampel atas kriteria penentuan yang sudah ditetapkan. 
Corporate

Governance and

Fraudulance

Teknik analisis data dalam penelitian ini menggunakan model analisis regresi logistik. Analisis ini bertujuan untuk mengetahui apakah Performa Dewan Komisaris, Keahlian Keuangan Komite Audit, dan Kepemilikan Institusional berpengaruh dalam mengurangi Kecurangan Laporan Keuangan. Model persamaan analisis regresi logistik dalam penelitian ini adalah sebagai berikut:

$$
\text { FRAUD }_{i}=\beta 0+\beta 1 \text { PBOCi }+\beta 2 \text { ACFEi }+\beta 3 \text { IOi }+\beta 4 \text { SIZEi }+\varepsilon
$$

Dimana penjelasan atas tiap-tiap variabel pada persamaan di atas yakni seperti berikut:

a. FRAUD = Dummy variabel dari penghitungan Beneish M-Score Model, dimana pemberian nilai 1 apabia perusahaan terindikasi kedalam kecurangan dan pemberian nilai 0 apabila perusahaan tidak terindikasi kedalam kecurangan.

b. PBOC = Performa Dewan Komisaris bersumber pada total rapat yang dilangsungkan Dewan Komisaris selama kurun waktu satu tahun.

c. $\mathrm{ACFE}=$ Keahlian Keuangan Komite Audit berdasarkan total anggota keahlian keuangan komite audit terhadap total semua anggota komite audit.

d. $\quad$ IO $=$ Kepemilikan institusional bersumber pada persentase Kepemilikan Saham Institusional kepada total saham perusahaan yang outstanding di tahun $t$.

e. SIZE = Ukuran perusahaan dilakukan pengukuran bersumber pada logaritma natural dengan proksi total asset perusahaan i.

f. $\varepsilon=$ Error

g. $\quad \beta_{1}, \beta_{2} \ldots \beta_{4}=$ Koefisien regresi masing-masing proksi

Tabel 1. Kriteria Pemilihan Sampel Penelitian

\begin{tabular}{lc}
\multicolumn{1}{c}{ Kriteria } & Jumlah \\
\hline Total perusahaan manufaktur yang tercatat pada BEI pada periode & 166 \\
tahun 2016-2018 & $\mathbf{1 6 6}$ \\
Jumlah populasi & $(3)$ \\
Perusahaan terdelisting selama periode penelitian & $(46)$ \\
Laporan tahunan atau laporan keuangan tidak tersedia di BEI atau & \\
website masing-masing perusahaan & $(67)$ \\
Perusahaan dengan data yang tidak sesuai dengan penelitian & $\mathbf{5 0}$ \\
Total seluruh sampel perusahaan & $\mathrm{x3}$ \\
Waktu observasi penelitian (dalam satuan tahun) & $\mathbf{1 5 0}$ \\
Jumlah Observasi & \\
\hline
\end{tabular}

Pengukuran Variabel

Variabel Dependen

Pengukuran variabel guna kecurangan laporan keuangan yang dilakukan pada penelitian ini memakai dummy variabel yang didapat dengan menggunakan perhitungan Beneish M-Score Model, dimana hasil tersebut akan merepresentasikan keadaan laporan keuangan perusahaan. Apabila keluaran Beneish M-Score memperlihatkan nilai lebih besar daripada $-2,22$, sehingga mengakibatkan hal itu mengindikasikan bahwa kemungkinan adanya kecurangan dalam laporan keuangan dan sampel akan diberikan kode [1]. Sebaliknya, apabila keluaran Beneish M-Score memperlihatkan nilai lebih kecil daripada 2,22 , sehingga mengakibatkan hal itu memberikan indikasi bahwa kemungkinan tidak adanya kecurangan dalam laporan keuangan dan sampel akan diberikan kode [0]. Berikut rumus dari Beneish $M$-Score:

\section{M-Score $=-4.84+0.920 \mathrm{DSRI}+0.528 \mathrm{GMI}+0.404 \mathrm{AQI}+0.892 \mathrm{SGI}+$ 0,11DEPI - 0.172SGAI - 0.32LEVI + 4.697TATA}

Apabila hasil perhitungan Beneish M-Score memperlihatkan nilai lebih besar daripada 2,22 , sehingga mengakibatkan hal itu mengindikasikan bahwa kemungkinan adanya kecurangan dalam laporan keuangan dan sampel akan diberikan kode [1]. Sebaliknya, apabila keluaran Beneish $M$-Score memperlihatkan nilai lebih kecil daripada -2,22, sehingga mengakibatkan hal itu memberikan indikasi bahwa kemungkinan tidak adanya kecurangan dalam laporan keuangan dan sampel akan diberikan kode [0].

Variabel Independen 
Perhitungan variabel yang dilaksanakan pada penelitian ini memakai total rapat Dewan Komisaris. Total rapat Dewan Komisaris yakni rapat yang dilaksanakan diantara Dewan Komisaris pada sebuah perusahaan. Indikator yang dipakai yakni total rapat yang dilaksanakan dari Dewan Komisaris pada kurun waktu satu tahun (Suhardjanto, 2010). Performa Dewan Komisaris = Jumlah rapat yang dilakukan Dewan Komisaris dalam satu tahun Keahlian Keuangan Komite Audit $\left(\mathbf{X}_{2}\right)$

Perhitungan variabel yang dilaksanakan di penelitian ini memakai pengukuran dengan memakai indikator presentase anggota keahlian keuangan komite audit kepada total semua anggota komite audit.

$$
\text { Keahlian Keuangan Komite Audit }=\frac{\text { Jumlah Anggota Keahlian Keuangan }}{\text { Jumlah Anggota Komite Audit }}
$$

\section{Kepemilikan Institusional $\left(\mathrm{X}_{3}\right)$}

Perhitungan variabel yang dilaksanakan pada penelitian ini memakai rumus total jumlah saham yang dipunya institusi dibagi total jumlah saham yang beredar Prasetyo (2016).

$$
\text { Kepemilikan Institusional }=\frac{\text { Jumlah saham yang dimiliki institusi }}{\text { Jumlah saham yang beredar }}
$$

\section{Variabel Kontrol \\ Ukuran Perusahan}

Ukuran perusahaan dinilai lewat memakai logaritma natural berdasar total assets perusahaan. Keadaan tersebut sama dengan riset sebelumnya yang menjadi acuan.

\section{Pengembangan Hipotesis}

$$
\text { Size }=\operatorname{Ln} \text { (total assets) }
$$

Beasley (1996) dan Hwa-Hsien Hsu dan Chloe Yu-Hsuan Wu (2014) mengatakan bahwa karakteristik komisaris yang bersumber dari luar perusahaan menolong perusahaan dalam meminimalisasi peluang timbulnya manipulasi pada laporan keuangan. Akan tetapi, Kusumawati (2013), Priswita (2019) dan Wicaksono (2015) mengatakan jika keefektivan Dewan Komisaris tidak mempunyai efek pada peluang timbulnya kecurangan dalam laporan keuangan. Untuk itu, penelitian ini ingin melihat apakah tingkat efektivitas dari sebuah Dewan Komisaris dapat meminimalisasi peluang terjadinya manipulasi pada Laporan Keuangan.

$\mathrm{H}_{1}$ : Performa Dewan Komisaris berpengaruh positif dalam mengurangi kecurangan laporan keuangan.

\section{Pengaruh Keahlian Keuangan Komite Audit dalam Mengurangi Kecurangan Laporan} Keuangan

Anisa dan Andri (2012) dan Prasetyo (2014) mengungkapkan saat bertambah banyaknya anggota komite audit yang mempunyai dasar keuangan serta akuntansi sehingga bakal bertambah efektif untuk meminimalisir timbulnya manipulasi pelaporan keuangan hingga kemampuan keuangan Komite Audit yang ditinjau menggunakan pengungkapan manipulasi laporan keuangan berdampak besar pada manipulasi laporan keuangan. Sedangkan Mustafa dan Nourhene (2012) yang mengungkapkan pada penelitiannya jika keahlian akuntansi anggota komite audit tidak punya pengaruh besar pada penyalahgunaan asset. Karena pertama, komite menghabiskan waktu yang lebih sedikit meninjau laporan keuangan perusahaan serta pengawasan. Oleh sebab itu, bisa saja jika anggota yang memiliki kemampuan bisa mendapati penyelewengan akuntansi. Kedua, adanya anggota dengan kemampuan bisa mengakibatkan anggota lain menjadi tidak terlalu waspada.

$\mathrm{H}_{2}$ : Keahlian Keuangan Komite Audit berpengaruh positif dalam mengurangi kecurangan laporan keuangan.

\section{Pengaruh Kepemilikan Institusional dalam Mengurangi Kecurangan Laporan Keuangan}

Roberts dan Yuan (2009) menandakan mengenai kepemilikan institusional yang tinggi bisa memberi motivasi guna melaksanakan pemeriksaan ataupun pengamatan yang 
Corporate Governance and Fraudulance

302 semakin selektif pada prestasi kerja manajemen hingga mempunyai peluang manajemen agar melaksanakan kecurangan terhadap laporan keuangan bakal makin kecil. Sedangkan menurut Priswita (2019), Kepemilikan institusional tidak punya pengaruh kepada kecurangan laporan keuangan. Keadaan tersebut timbul sebab pihak institusi luar masih belum berpartisipasi aktif saat mengawasi tindakan manipulasi yang dilaksanakan oleh manajer.

$\mathrm{H}_{3}$ : Kepemilikan Institusional berpengaruh positif dalam mengurangi kecurangan laporan keuangan.

\section{HASIL DAN PEMBAHASAN}

\section{Analisis Statistik Deskriptif}

Analisis statistik deskriptif dipakai guna menggambarkan karakteristik data yang dipakai pada riset dengan penyampaian pada wujud yang bisa dimengerti, yang diketahui berdasar nilai minimal, nilai maksimal, nilai rerata, median, modus, standar deviasi, range, dan varian. Variabel FRAUD yakni dummy variable. FRAUD diberi nilai satu (1) jika perusahaan itu terindikasi bahwa menjalankan kecurangan dalam laporan keuangan dan diberi nilai nol (0) bila tidak terindikasi bahwa melaksanakan kecurangan dalam laporan keuangan.

Tabel 2. Variabel Dummy

\begin{tabular}{clcc}
\hline \multicolumn{1}{c}{ Kategori } & Jumlah Observasi & Persentase \\
\hline \multirow{2}{*}{ FRAUD } & Tidak melakukan kecurangan & 100 & 66,7 \\
\cline { 2 - 4 } & Melakukan kecurangan lap keuangan & 50 & 33,7 \\
\hline & Total & 150 & 100 \\
\hline
\end{tabular}

Sumber: Hasil olah data SPSS

Bersumber dalam tabel 2 bisa diketahui mengenai variabel FRAUD sebagai variabel dependen memiliki jumlah observasi 150 dengan sampel yang terbukti melaksanakan kecurangan laporan keuangan sebesar 50 perusahaan, sedangkan sampel yang tidak terbukti melaksanakan kecurangan laporan keuangan sebesar 100 perusahaan.

Tabel 3. Statistik Deskriptif

\begin{tabular}{cccccc}
\hline Variabel & $\mathrm{N}$ & Mean & Std. Deviation & Min & Max \\
\hline PBOC & 150 & 7,31 & 2,795 & 1 & 16 \\
\hline ACFE & 150 & 0,6123 & 0,2166 & 0,25 & 1 \\
\hline IO & 150 & 0,3089 & 0,2747 & 0,0012 & 0,9307 \\
\hline SIZE & 150 & 28,8262 & 1,2751 & 25,64 & 32,2502
\end{tabular}

Sumber: Hasil olah data SPSS

Bersumber dalam tabel 3, mendeskripsikan terkait statistik dekriptif semua variabel pada penelitian. Pada bagian variabel performa dewan komisaris, memperlihatkan nilai terkecil adalah 1 dan nilai terbesar sebesar 16, memiliki rata-rata sebesar 7,31 dengan standar deviasi yaitu 2,795. Variabel Keahlian keuangan komite memperlihatkan nilai terkecil yaitu 0,25 dan nilai terbesar sebesar 1, memiliki rata-rata sebesar 0,6123 dengan standar deviasi 0,2166. Variabel kepemilikan institusional, memperlihatkan nilai terkecil sebesar 0,0012 dan nilai terbesar yaitu 0,9307, memiliki rata-rata 0,3089 dengan standar deviasi sebesar 0,2747 , lalu pada variabel kontrol yaitu ukuran perusahaan mempunyai nilai terkecil sebesar 25,64 dan nilai terbesar yaitu 32,2502, memiliki rata-rata sebesar 28,8262 dengan standar deviasi 1,2751 .

\section{Asumsi Klasik}

\section{Uji Multikolinieritas}

Di model regresi logistik, hanya satu asumsi yang wajib dapat dipenuhi yakni distribusi normal pada error atas keluaran estimasi. Ketentuan itu tidak membutuhkan uji spesifik serta hampir dapat dipenuhi untuk seluruh macam data. Meskipun demikan, uji multikolinearitas pasti wajib dilaksanakan supaya memahami terdapat ataupun tidak korelasi linear diantara variabel independen pada model regresi tersebut. Ketentuan yang wajib dapat dipenuhi yakni tidak terdapatnya multikolinearitas. Berdasarkan data yang diperoleh, uji multikolinieritas pada penelitian ini bisa diketahui dalam tabel 4 . 


\begin{tabular}{lll}
\hline & Tolerance & VIF \\
\hline PBOC & 0,874 & 1,144 \\
\hline ACFE & 0,913 & 1,095 \\
\hline IO & 0,847 & 1,181 \\
\hline SIZE & 0,889 & 1,124 \\
\hline \multicolumn{2}{l}{ Dependent Variable: FRAUD } \\
\hline \multicolumn{2}{l}{ Sumber: Hasil olah data SPSS }
\end{tabular}

Bersumber dalam tabel 4 bisa diketahui mengenai nilai Variance Inflatin Factor (VIF) di semua variabel diatas lebih kecil daripada 10 serta nilai Tolerance di semua variabel lebih besar daripada 0,1 sehingga memiliki arti yakni tidak berlangsung hubungan diantara variabel terikat, kemudian menunjukkan variabel-variabel terikat yang dipakai sudah mencukupi syarat pengujian.

\section{Uji Hipotesis}

\section{Regresi Logistik (Logistic Regression)}

Dengan memakai hasil uji regresi logistik yang diperlihatkan pada variabel in the equation. Pada uji hipotesis memakai regresi logistik terpenuhi dengan variabel in the equation, di kolom signifikan dilakukan perbandingan menggunakan tingkat alpha $0,05(5 \%)$. Bila tingkat signifikansi $<0,05$ kemudian mengakibatkan hipotesis diterima. Selanjutnya dilakukan penyajian tabel variabel in the equation:

Tabel 5. Uji Hipotesis

\begin{tabular}{lcccccc}
\hline Variabel & B & S.E. & Wald & df & Sig. & $\operatorname{Exp(B)}$ \\
\hline PBOC & 0,138 & 0,068 & 4,128 & 1 & 0,042 & 1,148 \\
\hline ACFE & 0,424 & 0,857 & 0,245 & 1 & 0,620 & 1,529 \\
\hline IO & 1,759 & 0,707 & 6,194 & 1 & 0,013 & 5,805 \\
\hline SIZE & 0,17 & 0,149 & 1,306 & 1 & 0,253 & 1,186 \\
\hline Constant & $-7,454$ & 4,489 & 2,757 & & 0,097 & 0,001 \\
\hline Sumber: Hasil olah data SPSS & & & &
\end{tabular}

Tabel tersebut memperlihatkan hasil uji menggunakan regresi logistik di tingkat signifikansi $5 \%$. Berdasar uji yang menggunakan regresi logistik tersebut sehingga didapatkan persamaan regresi logistik yakni seperti berikut:

FRAUD = -7,454 + 0,138 PBOC + 0,424 ACFE + 1,759 IO + 0,17 SIZE + $\varepsilon$

Keterangan:

Fraud = Kecurangan Laporan Keuangan

PBOC $=$ Performa Dewan Komisaris

ACFE = Keahlian Keuangan Komite Audit

IO = Kepemilikan Institusional

SIZE = Ukuran Perusahaan

$\varepsilon \quad=$ Error

\section{Uji Statistik}

Menilai Keseluruhan Model (Overall Model Fit)

Tabel 6. Uji Overall Test Step 0

\begin{tabular}{ccc}
\hline \multicolumn{2}{c}{ Iteration History $^{\mathbf{a}, \mathbf{b}, \mathbf{c}}$} \\
\hline & $\mathbf{- 2}$ Log likelihood & Coefficients $^{\text {Constant }}$ \\
\hline $\mathbf{1}$ & 190,978 &,- 667 \\
\hline $\mathbf{2}$ & 190,954 &,- 693 \\
\hline $\mathbf{3}$ & 190,954 &,- 693 \\
\hline a. & $\begin{array}{l}\text { Nilai konstan termasuk ke dalam model ini } \\
\text { b. }\end{array}$ & -2 Log Likelihood awal sebesar 190,954 \\
c. & $\begin{array}{l}\text { Estimasi diakhiri pada iterasi nomor 3 karena estimasi parameter mengalami } \\
\text { perubahan yang berkurang dari 0,001. }\end{array}$ \\
\hline
\end{tabular}

Sumber: Hasil olah data SPSS 
Corporate

Governance and

Fraudulance
Dalam Uji Overall test (Kesuluhan Model) regresi diperlihatkan dengan log likelihood value yakni selisih diantara -2log likelihood block 0 . Landasan pengukurannya yakni jika -2log likelihood block=1 lebih kecil daripada nilai $-2 \log$ likelihood block=0, sehingga menambahkan variabel ke dalam model membenahi model fit.

Tabel 7. Uji Overall Test Step 1

\begin{tabular}{ccccccc}
\hline & \multicolumn{7}{c}{ Iteration History $\mathbf{a , b}, \mathbf{c}, \mathbf{d}$} \\
\hline & $\mathbf{- 2 ~ L o g}$ & \multicolumn{5}{c}{ Coefficients } \\
\cline { 3 - 7 } & likelihood & Constant & PBOC & ACFE & IO & SIZE \\
\hline $\mathbf{1}$ & $\mathbf{1 8 2 , 4 3 6}$ & $-6,404$ &, 120 &, 382 & 1,540 &, 144 \\
\hline $\mathbf{2}$ & $\mathbf{1 8 2 , 1 8 9}$ & $-7,417$ &, 138 &, 423 & 1,752 &, 169 \\
\hline $\mathbf{3}$ & $\mathbf{1 8 2 , 1 8 8}$ & $-7,454$ &, 138 &, 424 & 1,759 &, 170 \\
\hline $\mathbf{4}$ & $\mathbf{1 8 2 , 1 8 8}$ & $-7,454$ &, 138 &, 424 & 1,759 &, 170 \\
\hline
\end{tabular}

a. Method: Enter

b. Nilai konstan termasuk ke dalam model ini

c. -2 Log Likelihood awal sebesar 190,954

d. Estimasi diakhiri pada iterasi nomor 4 karena estimasi parameter mengalami perubahan yang berkurang dari 0,001 .

Sumber: Hasil olah data SPSS

Hasil diatas menunjukkan nilai dari -2log likelihood mengalami penyusutan yakni nilai -2log likelihood 0 atau sebelum dimasukkan variabel independen sebesar 190,954 turun menjadi 182,188 setelah variabel independen dimasukkan ke dalam (block 1). Penyusutan itu memperlihatkan mengenai model yang dihipotesis fit dengan dengan data serta pemberian tambahan variabel bebas dapat memperbaiki model.

\section{Koefisien Determinasi (Nagelkerke R Square)}

Koefisien determinasi dapat dilihat dari nilai Nagelkerke's $R$ Square. Nilai itu dikenal pula yakni Pseudo $R$ Square guna mengetahui kapabilitas variabel bebas ketika menerangkan variabel terikat. Berikut disajikan tabel Model Summary:

Tabel 8. Uji Nagelkerke R Square

\begin{tabular}{cccc}
\hline \multicolumn{3}{c}{ Model Summary } \\
\hline & -2 Log likelihood & Cox \& Snell $\boldsymbol{R}$ Square & Nagelkerke $\boldsymbol{R}$ Square \\
\hline 1 & 182,188 & 0,057 & 0,079 \\
\hline
\end{tabular}

a. Estimasi diakhiri pada iterasi nomor 4 karena estimasi parameter berubah kurang dari 0.001

Sumber: Hasil olah data SPSS

Hasil memperlihatkan bahwa 0,079 atau 7,9\% variasi kecurangan laporan keuangan bisa diterangkan dari variabel bebas (performa dewan komisaris, keahlian keuangan komite audit serta kepemilikan institusional). Hasil ini juga menunjukkan sebesar 92,1\% (100\%-7,9\%) variasi kecurangan laporan keuangan bisa diterangkan dari variabel lainnya diluar riset.

\section{Goodness of Fit Test}

Uji Goodness of Fit Test memiliki tujuan agar memahami tingginya pengaruh variabel bebas dengan bersamaan kepada variabel terikat. Hasil dari pengujian Goodness of Fit Test bisa diketahu dari tabel omnibus seperti dibawah ini:

Tabel 9. Uji Goodness of Fit Test

\begin{tabular}{|c|c|c|c|}
\hline \multicolumn{4}{|c|}{ Hosmer and Lemeshow Test } \\
\hline & Chi-square & df & Sig. \\
\hline 1 & 8,909 & 8 & 0,350 \\
\hline
\end{tabular}

Bersumber dalam tabel 9 diperoleh nilai chi square sejumlah 8,909 dan nilai signifikansi sejumlah 0,350 yang memiliki arti $>0,05$ atau $\mathrm{H} 0$ diterima. Keadaan tersebut memperlihatkan mengenai variabel bebas yang digunakan yaitu Corporate Governance (performa dewan komisaris, keahlian keuangan komite audit serta kepemilikan 
institusional) dengan bersama-sama punya pengaruh kepada kecurangan laporan keuangan.

Pembahasan

\section{Pengaruh Performa Dewan Komisaris dalam Mengurangi Kecurangan Laporan Keuangan}

Berdasarkan hasil uji hipotesis di tabel 5 untuk variabel PBOC, diketahui memiliki koefisien sebesar 0,138 dengan nilai signifikan sejumlah 0,042 . Hasil penelitian ini memperlihatkan signifikansi lebih kecil daripada 0,05 (5\%) yang maknanya ada korelasi kuadratik diantara jumlah rapat dewan komisaris untuk mengurangi kecurangan laporan keuangan dan dari hasil ini dapat membuktikan adanya pengaruh performa dewan komisaris dalam mengurangi kecurangan laporan keuangan. Hasil ini mendukung hipotesis $\left(\mathrm{H}_{1}\right)$.

Kemudian, data yang digunakan dalam penelitian ini sebanyak 150 sampel dari 50 perusahaan manufaktur, diketahui bahwa perusahaan yang sering melakukan rapat atau diatas nilai rata-rata yaitu 7,31 terdapat sebanyak 45 data sampel dan dalam data sampel tersebut ada 17 atau 38\% sampel data yang melakukan kecurangan dan 28 atau $62 \%$ yang tidak melakukan kecurangan. Hal ini mengindikasikan bahwa seringnya rapat yang dilakukan dewan komisaris dapat mengurangi kecurangan yang dilakukan oleh para manejemen.

Hasil penelitian ini sesuai dengan hasil penelitian yang dilakukan oleh (Muller (2014), dalam Janggu et al, 2014) yang menyatakan bahwa performa yang dilakukan oleh Dewan Komisaris akan sangat berdampak pada performa perusahaan. Semakin tinggi tingkat efektivitas performa Dewan Komisaris, maka semakin tinggi pula performa perusahaan dan semakin tinggi pula kualitas laporan keuangan yang dibuat perusahaan. Jansen (1993) menyatakan bahwa dengan diterapkannya good corporate governance, diharapkan pengawasan dewan komisaris dapat meminimalisir dorongan manajer untuk melakukan tindakan manipulasi data keuangan, sehingga kinerja yang dilaporkan merefleksikan keadaan ekonomi yang sebenarnya dari perusahaan yang bersangkutan.

Namun hasil riset ini tidak searah pada riset Kusumawati (2013) dan Wicaksono (2015), yaitu mengatakan mengenai efektivitas dewan komisaris tidak mempunyai efek untuk mengecilkan berlangsungnya kecurangan dalam laporan keuangan. Demikian juga hasil penelitian oleh priswita (2019) memperlihatkan mengenai total rapat dewan komisaris tidak punya pengaruh terhadap kecurangan laporan keuangan yang bisa dilakukan oleh manajer perusahaan. Karena terdapat beberapa perusahaan di Indonesia mengimplementasikan praktik corporate governance semata-mata menjadi formalitas supaya tidak terkena sanksi dari regulator. Implementasi corporate governance masih merupakan perihal yang aktual di Indonesia serta pengaruh atas implementasi corporate governance itu baru bisa dirasakan pada kurun waktu yang lama.

\section{Pengaruh Keahlian Keuangan Komite Audit dalam Mengurangi Kecurangan Laporan}

\section{Keuangan}

Berdasarkan hasil uji di tabel 5 untuk variabel ACFE, diketahui mempunyai koefisien sejumlah 0,424 dengan nilai signifikan sejumlah 0,620. Hasil penelitian ini memperlihatkan signifikansi lebih besar daripada 0,05 (5\%) yang memperlihatkan mengenai variabel keahlian keuangan komite audit tidak punya pengaruh untuk mengurangi kecurangan laporan keuangan. Keadaan tersebut mengindikasi terkit jumlah komite audit yang berkeahlian keuangan belum bisa mengatasi masalah kecurangan laporan keuangan serta hasil tersebut tidak mendukung hipotesis $\left(\mathrm{H}_{2}\right)$.

Berdasarkan hasil dari penelitian ini yang diukur menggunakan jumlah komite audit yang mempunyai keahlian keuangan dengan jumlah seluruh komite audit tidak mempunyai pengaruh dalam mengurangi kecurangan. Hal ini dapat disebabkan karena komite yang berkeahlian keuangan hanya mempunyai waktu yang sangat singkat untuk meninjau dan mengontrol laporan keuangan. Salah satu contoh perusahaan yang mempunyai komite berkeahlian keuangan begitu banyak, namun terindikasi melakukan kecurangan yaitu pada PT Alakasa Industrindo Tbk (ALKA) di tahun 2017 dan 2018, 
Corporate

Governance and

Fraudulance

yang mempunyai 3 komite berkeahlian keuangan dari 3 komite audit yang ada pada perusahaan tersebut.

Hasil riset ini sesuai dengan riset yang dilaksanakan Mustafa dan Nourhene (2012) yang mengungkapkan pada risetnya mengenai keahlian akuntansi komite audit tidak punya pengaruh signifikan kepada penyalahgunaan asset. karena, komite menyelesaikan waktu yang relatif sedikit untuk meninjau laporan keuangan perusahaan serta kontrol. Oleh sebab itu, kemungkinan anggota dengan keahliannya bisa mendapati penyelewengan akuntansi dan kehadirannya dapat menyebabkan anggota lain menjadi kurang waspada.

Namun hasil riset ini tidak searah pada riset Prasetyo (2014) dan Annisa dan Andri (2012) yang punya pendapat mengenai semakin banyak persentase keahlian keuangan komite audit dalam sebuah perusahaan, sehingga perusahaan cenderung tidak terindikasi kecurangan laporan keuangan. Ini disebabkan karena keahlian keuangan komite audit diharapkan dapat mengerti dalam menyajian laporan keuangan yang baik serta mengetahui tindakan kecurangan yang dapat dilakukan didalam penyusunan laporan keuangan. Kemudian dengan makin banyaknya persentase komite audit yang berkeahlian keuangan pada perusahaan, cenderung dapat mendeteksi dan menekan peluang kecurangan laporan keuangan perusahaan.

\section{Pengaruh Kepemilikan Institusional dalam Mengurangi Kecurangan Laporan Keuangan}

Bersumber dalam hasil uji di tabel 5 untuk variabel IO, diketahui mempunyai koefisien sejumlah 1,759 dengan nilai signifikan sejumlah 0,013. Hasil penelitian ini memperlihatkan signifikansi lebih kecil daripada 0,05 (5\%) yang memperlihatkan mengenai variabel kepemilikan institusional punya pengaruh untuk mengurangi kecurangan laporan keuangan. Hasil ini mendukung hipotesis $\left(\mathrm{H}_{3}\right)$.

Berdasarkan data yang digunakan dalam penelitian ini sebanyak 150 sampel dari 50 perusahaan manufaktur, diketahui bahwa perusahaan yang memiliki kepemilikan institusional di atas rata-rata yaitu 0,308 terdapat sebanyak 62 data sampel dan dalam data sampel tersebut ada 22 atau 35\% sampel data yang melakukan kecurangan dan 40 atau $65 \%$ yang tidak melakukan kecurangan. Hal ini membuktikan bahwa kepemilikan institusional yang besar dalam sebuah perusahaan akan mengurangi kecurangan laporan keuangan dan juga investor institusional dapat memberikan pengawasan yang dapat mendorong manajemen untuk lebih fokus pada pencapaian kinerjanya sehingga dapat mengurangi terjadinya kecurangan pada laporan keuangan.

Hasil riset ini sesuai dengan riset yang dilaksanakan oleh Syamsudin (2017) yang menyatakan bahwa kepemilikan institusional yang tinggi akan mengakibatkan kinerja pihak manajemen dapat diawasi secara optimal. Dengan pengawasan yang dilakukan, pihak manajemen akan menghindari tindakan yang dapat merugikan pemegang saham. Usaha yang dilakukan dalam pengawasan akan lebih efektif, karena dapat mengendalikan tindakan - tandakan yang bersifat opportunistic yang akan dilakukan manajemen. Roberts dan Yuan (2009) punya pendapat pula bahwa kepemilikan institusional yang tinggi bisa memberi motivasi guna melaksanakan pemeriksaan ataupun pengamatan yang semakin selektif pada prestasi kerja manajemen hingga mempunyai peluang manajemen agar melaksanakan kecurangan terhadap laporan keuangan bakal makin kecil.

Rahardian (2008) punya pendapat pula mengenai pengaruh kepemilikan institusional pada perusahaan terpengaruhi dari tujuan investasi institusi itu. Investor institusional yang dalam kurun waktu rendah bakal punya pengaruh negatif kepada prestasi kerja perusahaan. Koh (2003) mengemukakan mengenai di perusahaan di Australia yang memiliki kepemilikan institusional yang besar dapat mendesak tata kelola laba yang agresif oleh perusahaan, yang mana kepemilikan institusional berperan selaku metode corporate governance.

Namun hasil riset ini tidak searah pada riset Salim (2017), Pihak pemegang saham institusi luar masih belum memiliki peran aktif untuk megawasi tindakan kecurangan 
yang dilangsungkan dari manajer, sehingga masih ada celah untuk manajer dalam melakukan kecurangan laporan keuangan.

\section{PENUTUP}

Berdasarkan pembahasan hasil yang telah dilakukan, maka dapat diambil kesimpulan bahwa performa dewan komisaris dan kepemilikan institusional dalam penelitian ini mampu mengurangi kecurangan laporan keuangan, sedangkan untuk keahlian keuangan komite audit belum mampu mengurangi kecurangan dalam laporan keuangan.

Penelitian ini punya beberapa keterbatasan, yang diangankan di riset berikutnya bisa dilaksanakan peningkatan makin lanjut. Keterbatasan pada penelitian yakni variabel kepemilikan institusional yang digunakan pada penelitian ini hanya digambarkan melalui total saham yang dipunya pihak institusi luar perusahaan per total saham yang beredar.

Saran teoritis yang dapat digunakan untuk penelitian selanjutnya ialah menambahkan variabel independen lainnya yang dapat mempengaruhi dalam mengurangi kecurangan laporan keua ngan seperti kualitas audit, komisaris independen dan lainnya. Dari segi praktis, penelitian ini memberikan saran pada perusahaan sektor non keuangan, pada perusahaan tersebut sebaiknya melakukan mekanisme peningkatan corporate governance dengan program pelatihan terhadap dewan komisaris, komite auditt, dan lain-lain pada perusahaan. Adanya program tersebut, bisa meminimalisir masalah kecurangan pada kecurangan laporan keuangan yang dilakukann oleh manajer.

\section{DAFTAR PUSTAKA}

Acharya, V. V., Myers, S. C., \& Rajan, R. G. (2011). Internet Appendix to "The Internal Governance of Firms". The Journal of Finance, LXVI(3), 1-8.

Chen, G., Firth, M., Gao, D. N., \& Rui, O. M. (2006). Ownership structure, corporate governance, and fraud: Evidence from China. Journal of Corporate Finance, 12(3), 424-448.

Eisenhardt, K. M., \& Eisenhardt, K. M. (2018). Linked references are available on JSTOR for this article: Agency Theory: An Assessment and Review. 14(1), 57-74.

Ghozali, I. (2018). Aplikasi Analisis Multivariate dengan Program SPSS 25. Edition 9. Semarang: Badan Penerbit Universitas Diponegoro.

Handoko, B. L., \& Ramadhani, K. A. (2017). Pengaruh Karakteristik Komite Audit, Keahlian Keuangan Dan Ukuran Perusahaan Terhadap Kemungkinan Kecurangan Laporan Keuangan. DeReMa Jurnal Manajemen, 12(1), 86-113.

Hsu, H. H., \& Wu, C. Y. H. (2014). Board composition, grey directors and corporate failure in the UK. British Accounting Review, 46(3), 215-227.

Janggu, T., Darus, F., Zain, M. M., \& Sawani, Y. (2014). Does Good Corporate Governance Lead to Better Sustainability Reporting? An Analysis Using Structural Equation Modeling. Procedia - Social and Behavioral Sciences, 145, 138-145.

Jannah, R. (2014). Pengaruh Corporate Governance terhadap Kinerja Keuangan Perusahaan (Studi pada Sub Sektor Perkebunan Periode 2009 - 2012). Jurnal Ilmu Manajemen, 4(1), 287509.

Kirana, D. J. (2019). Peranan Corporate Governance Dalam Meningkatkan Kinerja Perusahaan Family Ownership Di Indonesia. 1(2), 493-499.

Kusumawati, S. M., \& Hermawan, A. A. (2013). The Influence of Board of Commissioners and Audit Committee Effectiveness, Ownership Structure, Bank Monitoring, and Firm Life Cycle on Accounting Fraud. Jurnal Akuntansi Dan Keuangan Indonesia, 10(1), 20-39.

Lakshan, A. M. I., \& Wijekoon, W. M. H. N. (2012). Corporate Governance and Corporate Failure. Procedia Economics and Finance, 2(Af), 191-198.

Lins, K. V., \& Warnock, F. E. (2004). Corporate Governance and the Shareholder Base. International Finance Discussion Paper, 2004(816), 1-42.

Prasetyo, A. B. (2016). Pengaruh Karakteristik Komite Audit, Perusahaan dan Struktur Kepemilikan Terhadap Kecurangan Pelaporan Keuangan. SAR (Soedirman Accounting Review) : Journal of Accounting and Business, 1(2), 50.

Priharta, A. (2017). Pengaruh Corporate Governance terhadap Integritas Laporan Keuangan.
Corporate
Governance and

Fraudulance 
JABE (Journal of Applied Business and Economic), 3(4), 234. statement fraud and feature selection using data mining techniques. Decision Support Systems, 50(2), 491-500.

Roberts, G., \& Yuan, L. E. (2010). Does institutional ownership affect the cost of bank borrowing? Journal of Economics and Business, 62(6), 604-626.

Skousen, C. J., Smith, K. R., \& Wright, C. J. (2011). Detecting and Predicting Financial Statement Fraud: The Effectiveness of the Fraud Triangle and SAS No. 99. SSRN Electronic Journal, 99.

Smulowitz, S., Becerra, M., \& Mayo, M. (2019). Racial diversity and its asymmetry within and across hierarchical levels: The effects on financial performance. Human Relations, 72(10), 1671-1696.

Utami, W. S., \& Januarti, I. (2014). Pengaruh Karakteristik Corporate Governance Terhadap Kemungkinan Terjadinya Cororate Failure. 3(1998), 1-11.

Uzun, H., Szewczyk, S. H., \& Varma, R. (2004). Board composition and corporate fraud. Financial Analysts Journal, 60(3), 33-43.

Volonté, C. (2015). Boards: Independent and committed directors? International Review of Law and Economics, 41, 25-37.

Wicaksono, G. S., \& Chariri, A. (2015). Mekanisme Corporate Governance Dan Kemungkinan Kecurangan Dalam Pelaporan Keuangan. 4(4), 552-563. 